\title{
Genetic structure among continental and island populations of gyrfalcons
}

\author{
JEFF A. JOHNSON,${ }^{*}+$ KURT K. BURNHAM,${ }^{*} \ddagger$ WILLIAM A. BURNHAM*and DAVID P. MINDELL + \\ *The Peregrine Fund, 5668 West Flying Hawk Lane, Boise, ID 83709, USA, +University of Michigan Museum of Zoology and \\ Department of Ecology E Evolutionary Biology, 1109 Geddes Avenue, Ann Arbor, MI 48109, USA, ‡Edward Grey Institute of Field \\ Ornithology, Department of Zoology, University of Oxford, South Parks Road, Oxford OX1 3PS, UK
}

\begin{abstract}
Little is known about the possible influence that past glacial events have had on the phylogeography and population structure of avian predators in the Arctic and sub-Arctic. In this study, we use microsatellite and mitochondrial control region DNA variation to investigate the population genetic structure of gyrfalcons (Falco rusticolus) throughout a large portion of their circumpolar distribution. In most locations sampled, the mtDNA data revealed little geographic structure; however, five out of eight mtDNA haplotypes were unique to a particular geographic area (Greenland, Iceland, or Alaska) and the Iceland population differed from others based on haplotype frequency differences $\left(F_{\mathrm{ST}}\right)$. With the microsatellite results, significant population structure $\left(F_{\mathrm{ST}}\right.$, principal components analysis, and cluster analysis) was observed identifying Greenland and Iceland as separate populations, while Norway, Alaska and Canada were identified as a single population consistent with contemporary gene flow across Russia. Within Greenland, differing levels of gene flow between western and eastern sampling locations was indicated with apparent asymmetric dispersal in western Greenland from north to south. This dispersal bias is in agreement with the distribution of plumage colour variants with white gyrfalcons in much higher proportion in northern Greenland. Lastly, because the mtDNA control region sequence differed by only one to four nucleotides from a common haplotype among all gyrfalcons, we infer that the observed microsatellite population genetic structure has developed since the last glacial maximum. This conclusion is further supported by our finding that a closely related species, the saker falcon (Falco cherrug), has greater genetic heterogeneity, including mtDNA haplotypes differing by 1-16 nucleotide substitutions from a common gyrfalcon haplotype. This is consistent with gyrfalcons having expanded rapidly from a single glacial-age refugium to their current circumpolar distribution. Additional sampling of gyrfalcons from Fennoscandia and Russia throughout Siberia is necessary to test putative gene flow between Norway and Alaska and Canada as suggested by this study.
\end{abstract}

Keywords: Arctic, Falco, microsatellite DNA, migration, mtDNA control region, population genetic structure

Received 8 February 2007; revision accepted 4 April 2007

\section{Introduction}

In arctic and subarctic vertebrates, varying amounts of intraspecific genetic differentiation have been documented,

Correspondence: Jeff A. Johnson, Fax: 734763 4080; E-mail: jeffaj@umich.edu

William A. Burnham passed away on 16 October 2006 largely consistent with dispersal capabilities, presence of potential barriers, and the influence of Quaternary climatic fluctuations on population history (Pamilo \& Savolainen 1999; Weider \& Hobæk 2000; Newton 2003; Hewitt \& Nichols 2005). For example, the occupancy of separate icefree refugia during glacial periods would allow divergence among taxa and the accumulation of unique traits through selection and drift (see Stewart \& Lister 2001; Hewitt 2004). 
Similarly, as populations expanded into large areas previously glaciated or unsuitable, rapid differentiation and divergence could also occur between populations as local adaptive responses develop through selection and drift, assuming that further immigration was limited (Hewitt 1996; Newton 2003).

For the gyrfalcon (Falco rusticolus), very little is known about its overall geographic differentiation and how past climactic changes may have influenced its current distribution. This species and the snowy owl (Nyctea scandiaca) are the only two large avian predators that inhabit the Arctic and sub-Arctic with a circumpolar distribution, and to our knowledge neither taxa have been studied at the population level while using genetic methods. Latitudinal breeding range for gyrfalcons extends from $54^{\circ} \mathrm{N}$ on the Kamchatka Peninsula in Russia and Hudson Bay in Canada to as far north as $82^{\circ} \mathrm{N}$ in Peary Land, Greenland, with populations generally distributed across six areas: Alaska, Canada, Greenland, Iceland, Fennoscandia, and Russia (Fig. 1; Koch 1925; Johnsen 1953; Cade 1982; Potapov \& Sale 2005).

Given its extensive geographic distribution, it is unusual that no subspecies are currently recognized for gyrfalcons; yet, this species is polytypic and previously as many as 40 different subspecies have been described (Vaurie 1961; Snow 1974; Cade et al. 1998; Potapov \& Sale 2005). Taxonomic designations used most often in the past include five to seven subspecies largely based on plumage colour. Gyrfalcons from northern Greenland and northeastern Canada are mostly white and white to semiwhite or silver, respectively (i.e. candicans); those from central to southern Greenland and North America are semiwhite or silver to grey to dark grey or black (i.e. obsoletus); those from Iceland are light grey to grey (i.e. islandus); in Fennoscandia and western Russia they are mostly grey (i.e. rusticolus); and in Siberia they are typically grey to light grey or white (i.e. intermedius, uralensis, grebnitzkii). These plumages, however, do not strictly conform to geography, with each 'colour morph' or 'variant', occurring in many of the same areas (Todd \& Friedmann 1947; Vaurie 1961; Cade et al. 1998; Flann 2003; Potapov \& Sale 2005) and different plumage variants have been observed between mates and among offspring at the same eyrie or nest (Todd \& Friedmann 1947; Todd 1963; White \& Cade 1971). However, there are geographic areas such as those in northern Greenland and Iceland that do have a high percentage of similarly coloured gyrfalcons observed among breeding individuals. These geographic differences in colour could be the result of adaptive responses to local environments, such as for camouflage or because of metabolic costs associated with pigment synthesis (Potapov \& Sale 2005; but see Cade 2006). However, local fixation of alleles associated with these differences would require restricted gene flow between populations, and little information exists on gyrfalcon immigration or dispersal patterns over long distances and between geographical areas (Cade et al. 1998; Potapov \& Sale 2005).

We used microsatellite and mitochondrial DNA (mtDNA) variation to investigate demographic history and gene flow among gyrfalcon populations throughout a large portion of their range in Alaska, Canada, Greenland, Iceland, and Norway. By using both types of markers, we can investigate temporal demographic processes that have helped shape the distribution of this species and determine whether differences in the frequency of colour variants are associated with connectivity between populations. Mitochondrial DNA sequence data can be useful for uncovering historical genealogical relationships among populations (i.e. phylogeography \& the influence of multiple glacial refugia), while multilocus microsatellite data are useful for investigating more recent demographic processes associated with population structure (i.e. dispersal \& gene flow; see Sunnucks 2000; DeYoung \& Honeycutt 2005; Anne 2006).

We have included genetic data from a closely related species, the saker falcon (Falco cherrug), to provide a measure of interspecific differentiation for comparison with gyrfalcon intraspecific differentiation. The saker falcon has a more southern distribution, occurring from central and eastern Europe into central Asia through Mongolia, and breeding from approximately $35^{\circ}$ to $60^{\circ} \mathrm{N}$ (Cade 1982; Snow \& Perrins 1998; Ferguson-Lees \& Christie 2001). Although the breeding ranges of the two falcon species do not overlap, they do appear to possess a recent common history based on studies documenting a shared mtDNA control region haplotype between these two taxa (Nittinger et al. 2005, 2007). By including saker falcons in this study, we can investigate the temporal aspect associated with the divergence of these two taxa, and in so doing provide a more thorough account of the demographic history associated with gyrfalcons.

\section{Materials and methods}

\section{Sampling and DNA extractions}

Blood or feather samples were collected from individual gyrfalcons $(n=165)$ at seven different geographic locations throughout Alaska, Greenland, Canada, and Iceland (Fig. 1). In Greenland, four geographic areas were sampled consisting of Thule, Kangerlussuaq, Scoresbysund, and Maniitsoq, and single geographic areas were sampled in each of the remaining three countries (see Fig. 1). All locations were sampled between 2001 and 2004 with the exception of Canada (1991-1992). Gyrfalcon samples were collected during the breeding season for all locations except Maniitsoq and Scoresbysund, where birds were collected during fall migration (September-November). Given their geographic locations, samples collected in Scoresbysund likely represent gyrfalcons from northeast Greenland, while those from Maniitsoq, located much 


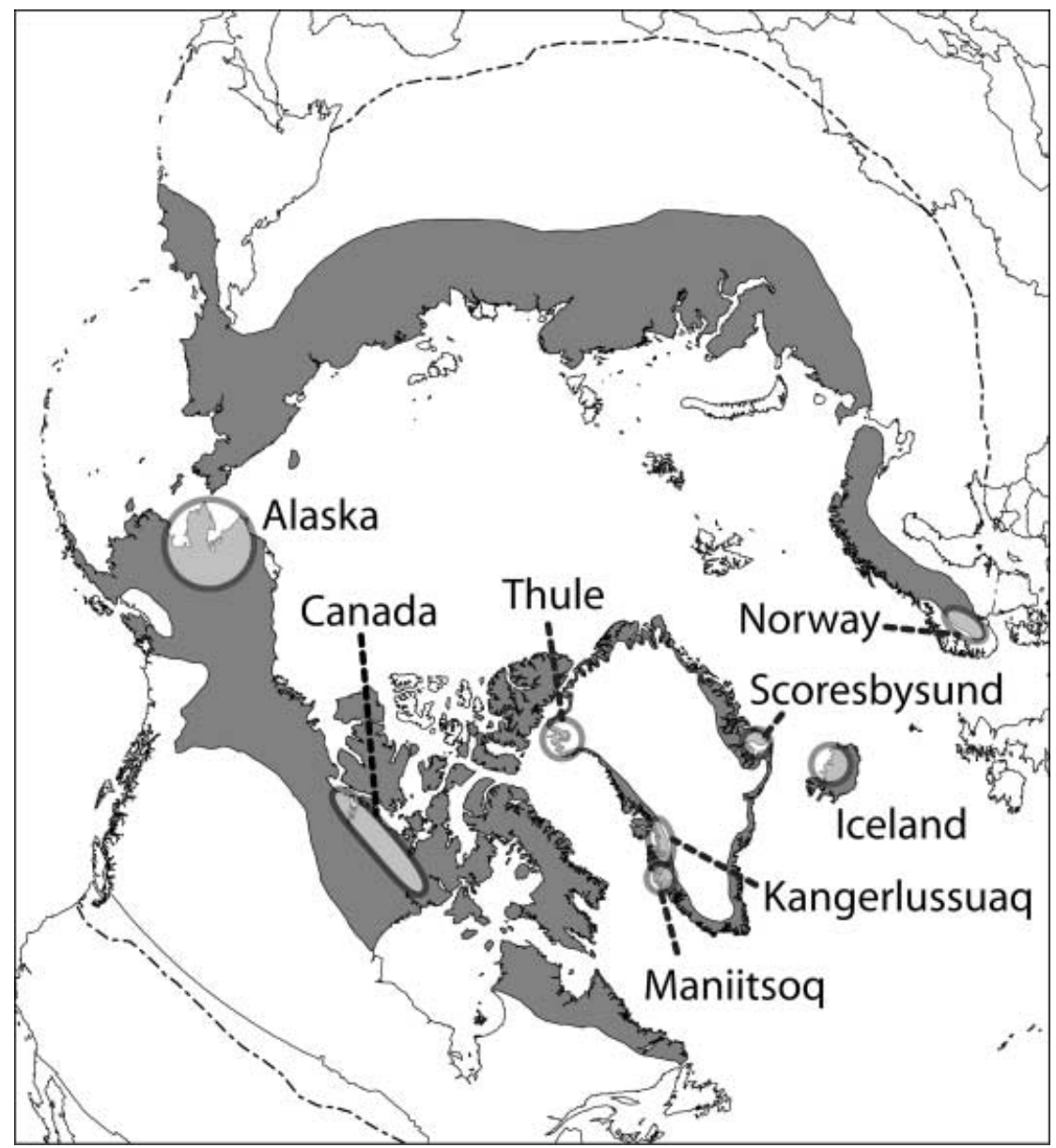

Fig. 1 Geographic distribution of gyrfalcons. Grey shading indicates the breeding distribution, while the broken line represents the southern edge of their wintering distribution. Sampling locations are shown with the size of each ellipse representing the approximate geographic area sampled.

further south may include a mixture of individuals from a much larger geographic area (Fig. 1). In locations sampled during the breeding season, one sample from each eyrie was included in the analyses, but in order to increase sample sizes at two locations (Thule \& Kangerlussuaq), we included multiple samples collected at the same eyrie from different years. To control for sampling the same individual over multiple years, we only included individuals from the same eyrie that possessed different mtDNA haplotypes, which is a conservative approach given the low variability in mtDNA haplotypes (see results). The gyrfalcon samples from Norway $(n=13)$ have been described elsewhere (Nesje et al. 2000) and samples $(n=3)$ were obtained from M. Nesje to calibrate the two microsatellite data sets. To provide a degree of interspecific differentiation that can be useful for comparative purposes, 20 individuals of a closely related taxon, the saker falcon (Falco cherrug), were sampled in the United Arab Emirates (UAE). These samples were collected during winter migration and likely represent individuals from multiple breeding origins. DNA was extracted from both blood and feather tissues using a DNeasy Tissue Extraction Kit (QIAGEN Inc.).

\section{Genotyping and sequencing}

Eight microsatellite loci originally developed for the peregrine falcon (Falco peregrinus; Fp13, Fp54, Fp79-4, Fp82-2, fp89, Fp92-1, \& Fp107; Nesje et al. 2000) and the gyrfalcon (Fr34; Nesje \& Røed 2000) were used for the microsatellite analyses. All microsatellite loci were dinucleotide repeats, and locus Fp107 had an imperfect core repeat. The polymerase chain reaction (PCR) amplifications were performed using the following reagents in a $10-\mu \mathrm{L}$ reaction: $50 \mathrm{ng}$ total genomic template, $0.5 \mu \mathrm{M}$ fluorescently labelled forward and unlabelled reverse primer, $1 \times$ buffer solution (Invitrogen), $1.0 \mathrm{~mm} \mathrm{MgCl}_{2}$ (except loci fp89, $\mathrm{fp} 107, \&$ fr 34 required $1.5 \mathrm{~mm}$ and fp82-2 required $2.0 \mathrm{~mm}$ ), $0.4 \mathrm{~mm}$ of each $\mathrm{dNTP}$, and $0.5 \mathrm{U}$ of Taq polymerase (Invitrogen). The PCR conditions consisted of one denaturing cycle at $94{ }^{\circ} \mathrm{C}$ for $4 \mathrm{~min}$, followed by 30 cycles at $94{ }^{\circ} \mathrm{C}$ for $40 \mathrm{~s}, 40 \mathrm{~s}$ at annealing temperature $\left(55^{\circ} \mathrm{C}\right.$ for all primers except fp13, fp79-4, and fp92-1 at $52^{\circ} \mathrm{C}$, and fp54 at $58^{\circ} \mathrm{C}$ ), and a 40 -s extension step at $72{ }^{\circ} \mathrm{C}$. This was followed by an extension step at $72{ }^{\circ} \mathrm{C}$ for $5 \mathrm{~min}$. Amplified products were diluted and run on an ABI 3730 automated sequencer. 
For the mtDNA analysis, 6 to 31 individuals were sequenced from each of the sampling locations used in the microsatellite analysis, with the exception of Norway where individual samples where not available for sequencing. Two primer pairs, 14532 L (5'-CCCACACATCAAACCAGAATG) $/ 15646 \mathrm{H}$ (5'-CTGACCGAGGAACCAGAGG) and 15573 L (5'-CACGAGGTTCGGACTACTGCCGTTGCA)/ 16090H (5'-AGATAAGATAACGGGATGGGTGT) were used to amplify approximately $1540 \mathrm{bp}$ of mtDNA sequence consisting of $298 \mathrm{bp}$ and $69 \mathrm{bp}$ of cytochrome $b$ (cyt $b$ ) and tRNAthr, respectively, and 1173 bp of the $5^{\prime}$ end of the control region (CR), including all of domains I and II and approximately $88 \mathrm{bp}$ of domain III (identified by conserved sequence block, CSB-1). Primer names correspond to the position of the $3^{\prime}$ nucleotide in the published peregrine falcon mtDNA genome (Mindell et al. 1999; GenBank Accession no: NC_000878). PCR amplification was performed in $25-\mu \mathrm{L}$ reaction volumes using $50 \mathrm{ng} / \mu \mathrm{L}$ genomic template, containing $0.5 \mu \mathrm{M}$ of each primer, $1.9 \mathrm{~mm}$ $(14532 \mathrm{~L} / 15646 \mathrm{H})$ or $1.2 \mathrm{~mm}(15573 \mathrm{~L} / 16090 \mathrm{H}) \mathrm{MgCl}_{2}, 1 \times$ buffer solution (Invitrogen), $0.8 \mathrm{~mm}$ of each $\mathrm{dNTP}$, and $1.25 \mathrm{U}$ of Taq polymerase. The PCR conditions were one denaturing cycle at $94{ }^{\circ} \mathrm{C}$ for $2 \mathrm{~min}$, followed by 35 cycles at $94{ }^{\circ} \mathrm{C}$ for $25 \mathrm{~s}, 60{ }^{\circ} \mathrm{C}$ for $25 \mathrm{~s}$, and an extension step for $1 \mathrm{~min}$ at $72^{\circ} \mathrm{C}$. This was followed by an extension step at $72{ }^{\circ} \mathrm{C}$ for $7 \mathrm{~min}$. Primers 15573L/16090H had PCR conditions that followed a touchdown procedure: annealing temperature from 70 to $60{ }^{\circ} \mathrm{C}\left(-2^{\circ} /\right.$ two cycles $)+58^{\circ} \mathrm{C}$ for 24 cycles. PCR products were directly sequenced in both directions with ABI Big Dye Terminator chemistry. All sequences were aligned using SEQUENCHER 4.2.2, and verified for accuracy. Unique sequences are in GenBank (accession nos EF517337-EF517355).

\section{Statistical analyses}

Microsatellite genotypes were tested for linkage equilibrium and departure from Hardy-Weinberg equilibrium within each population at each locus using the computer program GDA (Lewis \& Zaykin 2001). Sequential Bonferroni corrections were applied to correct for multiple simultaneous comparisons (Rice 1989). Mean number of alleles per locus (allelic diversity) and mean heterozygosity values were also calculated using GDA. Measures of allelic richness were calculated using the program FSTAT version 2.9.3.2 (Goudet 1995) to control for differences in the number of alleles among populations that differ in sample size (Leberg 2002). Mitochondrial DNA control region diversity was determined by calculating population estimates of haplotype diversity $(h)$, nucleotide diversity $(\pi)$, and Tajima's $D$ using the program DNASP version 4.00 (Rozas et al. 2003).

To investigate population genetic structure with both microsatellite and mtDNA among sampling locations, pairwise $F_{\mathrm{ST}}$ values were calculated following Weir \&
Cockerham (1984) as implemented in ARLEQUIN version 3.1 (Excoffier et al. 2005). Microsatellite pairwise $R_{\mathrm{ST}}$ (Slatkin 1995) values were also calculated using the program $R_{\mathrm{ST}} \mathrm{CALC}$ (Goodman 1997), however, our results with $F_{\mathrm{ST}}$ and $R_{\mathrm{ST}}$ were qualitatively similar (Pearson's $r=0.931, P<0.001$ ) and therefore we only report $F_{\mathrm{ST}}$ values here. Differences in population structure between sampling locations were tested using 10000 permutations among populations with Fisher's exact test. To visualize the genetic relationships among sampling locations, a multivariate ordination was conducted for the microsatellite data using PCAGEN (www.unil.ch/izea/softwares/pcagen.html) with 10000 randomization steps. In addition, the relationship between mtDNA haplotypes was visualized with a parsimony network estimated using the program TCs version 1.17 (Clement et al. 2000).

We also investigated spatial genetic structure using the Bayesian method of Pritchard et al. (2000) and Falush et al. (2003), implemented in the program STRUCTURE version 2.1. This method identifies genetically distinct clusters $(K)$ based on allele frequencies across loci. The most likely value of $K$ is assessed by comparing the likelihood of the data for different values of $K$. Calculations were conducted with a burn-in period of 100 000, followed by 500000 iterations. Each simulation was performed four times using an ancestry model incorporating admixture, individual alphas for each population, and a model of correlated allele frequencies that did not include prior information on population origin (see Falush et al. 2003).

The program BAYESASS version 1.3 (Wilson \& Rannala 2003) was used to estimate recent immigration rates, $m$ (i.e. proportion of migrants), among gyrfalcon breeding locations while using the microsatellite data. This Bayesian method does not require the populations to be in either migration drift or Hardy-Weinberg equilibrium, the violation of which can have important implications on the accuracy of migration estimates with other methods that require equilibrium conditions (Whitlock \& McCauley 1999; Kinnison et al. 2002). The Markov chain Monte Carlo (MCMC) method used in this program was run for $20 \times 10^{6}$ iterations with sampling every 2000 iterations, of which the first $10^{6}$ iterations were discarded as burn-in. Based on preliminary runs using different delta values (i.e. maximum parameter change per iteration) ranging from 0.05 to 0.35 , our final runs used delta values of $0.20,0.15$, and 0.24 for the parameters estimated for allele frequency, migration, and inbreeding, respectively, to ensure optimal mixing and maximize loglikelihood values (see BAYESASs documentation). Because of low sample size in the Canada population and the results given from other methods (e.g. $F_{\mathrm{ST}}$ \& STRUCTURE) indicating no genetic subdivision between the Alaska and Canada sampling locations, we combined these two locations as a single population with all other sampling locations kept separate. Initial trial runs with Alaska and Canada as 
Table 1 Microsatellite diversity for gyrfalcon and saker falcon sampling locations

\begin{tabular}{|c|c|c|c|c|c|}
\hline Sampling location & $n$ & Mean alleles/locus & Allelic richness & $H_{\mathrm{O}}$ & $H_{\mathrm{E}}$ \\
\hline \multicolumn{6}{|l|}{ Gyrfalcons } \\
\hline Alaska & 28 & $3.8(0.9)$ & $3.1(0.7)$ & $0.455(0.069)$ & $0.493(0.073)$ \\
\hline Canada & 9 & $3.0(0.8)$ & $2.9(0.7)$ & $0.396(0.079)$ & $0.414(0.091)$ \\
\hline Iceland & 25 & $3.5(1.0)$ & $3.0(0.7)$ & $0.428(0.081)$ & $0.444(0.084)$ \\
\hline Norway & 13 & $3.5(1.0)$ & $3.2(0.6)$ & $0.454(0.028)$ & $0.522(0.069)$ \\
\hline \multicolumn{6}{|l|}{ Greenland } \\
\hline Thule & 31 & $2.6(0.5)$ & $2.3(0.3)$ & $0.404(0.055)$ & $0.406(0.062)$ \\
\hline Kangerlussuaq & 16 & $3.0(0.7)$ & $2.7(0.5)$ & $0.352(0.094)$ & $0.432(0.092)$ \\
\hline Scoresbysund & 38 & $3.1(0.7)$ & $2.6(0.4)$ & $0.412(0.060)$ & $0.451(0.072)$ \\
\hline Maniitsoq & 18 & $2.9(0.5)$ & $2.7(0.4)$ & $0.438(0.068)$ & $0.470(0.071)$ \\
\hline \multicolumn{6}{|l|}{ Saker falcons } \\
\hline UAE & 20 & $5.4(1.3)$ & $4.2(0.9)$ & $0.469(0.087)$ & $0.570(0.096)$ \\
\hline
\end{tabular}

$n$, number of individuals sampled; $H_{\mathrm{O}^{\prime}}$ observed heterozygosity; $H_{\mathrm{E}^{\prime}}$ expected heterozygosity; standard error is given in parentheses.

separate populations confirmed this approach as estimates of $m$ between these two location were relatively high and the proportion of nonmigrants within each were close to $2 / 3$ (the minimum bound estimate; see program documentation). Four independent runs differing in the initial seed value were conducted to ensure convergence.

\section{Results}

\section{Genetic diversity}

Seven of the eight microsatellite loci were polymorphic in all gyrfalcon sampling locations (see Appendix). Locus Fp89 was monomorphic in Kangerlussuaq from Greenland, but polymorphic in all other sampling locations. After adjusting for multiple comparisons $(n=80)$, significant departures from Hardy-Weinberg equilibrium in the form of heterozygote deficiencies were observed in two loci among three sampled populations (Fp107, Alaska; Fp54, Norway; and Fp54, saker falcons). One pairwise comparison testing for linkage disequilibrium was significant in a single sampling location (Thule, Fp82-2 \& Fr34) after correcting for multiple comparisons $(n=280)$. Given the lack of significant linkage disequilibrium across all sampling locations, we conclude that the loci can be treated as independent from each other.

A total of 45 microsatellite alleles were observed among all geographic locations for gyrfalcons across eight loci, ranging from a maximum of 31 alleles in Alaska to a minimum of 21 alleles in Thule, while saker falcons possessed a total of 47 alleles across all loci (see Appendix). Four alleles were unique to Iceland, a single allele was unique to both Norway and Alaska, and saker falcons had 13 unique alleles that were not observed among gyrfalcons. Mean number of alleles per locus varied among sampling locations, with a high of 3.8 in Alaska and a low of 2.6 in Thule
(Table 1). Allelic richness was lowest in Thule, with all Greenland sampled areas ranging from 2.3 to 2.7, while all other gyrfalcon sampling locations ranged from 2.9 to $3.2 \%$. Observed heterozygosity $\left(H_{\mathrm{O}}\right)$ was also similar among sampled locations (Table 1). Saker falcons sampled in UAE had higher allelic diversity and $H_{\mathrm{O}}$ estimates than those obtained for each sampled gyrfalcon population.

Of the 1540 nucleotides scored for mtDNA, 10 nucleotide positions were variable among gyrfalcons, 24 among saker falcons, and a total of 30 were variable between gyrfalcons and saker falcons (all transitions; Table 2). All of the observed nucleotide variability among gyrfalcons was within domain I of the $\mathrm{CR}$, while variability was observed throughout the entire sequence among saker falcons. Three copies of an 80-bp tandem repeat were observed within domain I (bases 401-641; Table 2) of both gyrfalcon and saker falcon individuals. A single fixed nucleotide difference located in cyt $b$ (position 59; Table 2) distinguished the two falcon species. A total of eight and 11 haplotypes were observed among gyrfalcons and saker falcons, respectively. Number of haplotypes per location for gyrfalcons ranged from two in Scoresbysund and Iceland to a maximum of five in Kangerlussuaq (Table 3). Gyrfalcon haplotype diversity $(h)$ ranged from 0.239 in Scoresbysund to 0.800 in the Maniitsoq sampling location, while saker falcon $h$ was 0.868 . Nucleotide diversity $(\pi)$ was consistently low across all gyrfalcon locations (0.000-0.001), and polymorphism within each sampling location was consistent with neutral expectations (Tajima's $D=-1.367-1.531, P>0.05$ ).

\section{Population structure}

Gyrfalcon populations on islands (i.e. Greenland \& Iceland) appear distinct relative to mainland populations, as significant pairwise differentiation $\left(F_{\mathrm{ST}}\right)$ for microsatellite data was observed while controlling for multiple comparisons 
Table 2 Nineteen mtDNA haplotypes (Hap.) observed among gyrfalcon (A-H) and saker falcon (I-S) samples. See Fig. 2 for geographic information for each haplotype. Vertical numbers indicate the positions of variable nucleotides within 1540 bp of sequence (cyt $b$, bases $1-$ 298; tRNA, bases 299-367; CR domain I, bases 368-1002; CR domain II, bases 1003-1477; CR domain III, bases 1478-1540). Dots under nucleotide positions indicate an identical nucleotide as given with haplotype $\mathrm{A}$

\begin{tabular}{|c|c|c|c|c|c|c|c|c|c|c|c|c|c|c|c|c|c|c|c|c|c|c|c|c|c|c|c|c|c|c|}
\hline Hap. & & 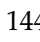 & & & & & & & & 469 & & 974 & 37 & & & & & & & & & & & 211 & & & 21 & & & 4148 \\
\hline A & G & A & C & C & $\mathrm{A}$ & $\mathrm{C}$ & C & A & C & A & A & $\mathrm{T}$ & A & G & A & C & A & C & G & $\mathrm{T}$ & G & $\mathrm{T}$ & A & $\mathrm{C}$ & C & $\mathrm{T}$ & A & A & $\mathrm{C}$ & A \\
\hline B & . & . & . & . & . & . & . & . & . & G & . & $\mathrm{C}$ & G & . & . & . & . & . & . & . & : & . & G & . & . & . & . & . & . & . \\
\hline C & . & . & . & . & . & . & . & . & . & . & G & . & . & . & . & . & . & . & . & . & . & . & . & . & . & . & . & . & . & . \\
\hline D & . & . & . & . & . & . & . & G & . & . & . & . & . & . & . & . & . & . & . & . & . & . & . & . & . & . & . & . & . & . \\
\hline E & . & . & . & . & . & . & . & . & . & . & . & . & . & . & . & . & G & . & . & . & . & . & . & . & . & . & . & . & . & . \\
\hline F & . & . & . & . & . & . & . & . & . & . & . & . & . & . & . & $\mathrm{T}$ & . & . & . & . & . & . & . & . & . & . & . & . & . & . \\
\hline G & . & . & . & . & . & . & . & . & . & . & G & . & . & . & . & . & . & . & . & . & A & . & . & . & . & . & . & . & . & . \\
\hline $\mathrm{H}$ & . & . & . & . & $\cdot$ & . & . & . & . & . & . & . & . & . & . & . & . & . & . & C & . & . & . & . & . & . & . & . & . & . \\
\hline I & A & . & . & . & $\mathrm{G}$ & . & . & . & . & . & . & . & . & . & . & . & . & $\mathrm{T}$ & . & . & A & . & . & . & . & . & . & . & . & . \\
\hline $\mathrm{J}$ & A & . & . & . & $\mathrm{G}$ & . & . & . & . & . & . & . & . & . & . & . & . & . & . & . & A & . & . & . & . & . & . & . & . & . \\
\hline K & $A$ & . & $\mathrm{T}$ & . & . & $\mathrm{T}$ & . & . & $\mathrm{T}$ & . & . & . & G & A & . & . & . & . & A & . & A & C & . & A & $\mathrm{T}$ & $\mathrm{C}$ & $\mathrm{G}$ & G & $\mathrm{T}$ & G \\
\hline $\mathrm{L}$ & A & . & . & . & . & . & . & . & . & . & . & . & . & . & . & . & . & . & . & . & . & . & . & . & . & . & . & . & . & . \\
\hline $\mathrm{M}$ & A & . & $\mathrm{T}$ & . & . & $\mathrm{T}$ & . & . & $\mathrm{T}$ & . & . & . & $\mathrm{G}$ & . & . & . & . & . & A & . & $\mathrm{A}$ & C & . & $\mathrm{A}$ & $\mathrm{T}$ & $\mathrm{C}$ & $\mathrm{G}$ & $\mathrm{G}$ & $\mathrm{T}$ & G \\
\hline $\mathrm{N}$ & A & . & . & . & . & . & . & . & . & . & . & . & . & . & . & . & . & . & . & . & $\mathrm{A}$ & . & . & . & . & . & $\mathrm{G}$ & . & . & . \\
\hline $\mathrm{O}$ & $\mathrm{A}$ & . & . & . & . & . & . & . & . & . & . & . & . & . & . & . & . & . & $\mathrm{A}$ & . & $\mathrm{A}$ & . & . & . & . & . & . & . & . & . \\
\hline $\mathrm{P}$ & A & . & . & . & . & . & . & . & . & . & . & . & . & . & G & . & . & . & A & . & $\mathrm{A}$ & . & . & . & . & . & . & . & . & . \\
\hline$Q$ & A & G & $\mathrm{T}$ & . & . & $\mathrm{T}$ & . & . & $\mathrm{T}$ & G & . & . & $\mathrm{G}$ & . & . & . & . & . & A & . & A & . & . & $\mathrm{A}$ & $\mathrm{T}$ & $\mathrm{C}$ & $\mathrm{G}$ & $\mathrm{G}$ & $\mathrm{T}$ & G \\
\hline $\mathrm{R}$ & $A$ & . & $\mathrm{T}$ & $\mathrm{T}$ & . & $\mathrm{T}$ & $\mathrm{T}$ & . & . & . & . & . & $\mathrm{G}$ & . & . & . & . & . & . & . & A & C & . & $\mathrm{A}$ & $\mathrm{T}$ & $\mathrm{C}$ & $\mathrm{G}$ & G & $\mathrm{T}$ & $\mathrm{G}$ \\
\hline$S$ & $A$ & . & $\mathrm{T}$ & . & . & $\mathrm{T}$ & . & . & $\mathrm{T}$ & . & G & . & $\mathrm{G}$ & . & . & . & . & . & A & . & $\mathrm{A}$ & . & . & A & $\mathrm{T}$ & $\mathrm{C}$ & $\mathrm{G}$ & G & $\mathrm{T}$ & G \\
\hline
\end{tabular}

Table 3 Mitochondrial cyt $b / C R(1540 \mathrm{bp})$ genetic diversity for gyrfalcon and saker falcon sampling locations. $n$, number of individuals sampled; standard error values are given in parentheses

\begin{tabular}{|c|c|c|c|c|c|}
\hline Sampling location & $n$ & No. of haplotypes & Haplotype diversity $(h)$ & Nucleotide diversity $(\pi)$ & Tajima's $D+$ \\
\hline \multicolumn{6}{|l|}{ Gyrfalcons } \\
\hline Alaska & 20 & 4 & $0.647(0.020)$ & $0.001(0.000)$ & 0.039 \\
\hline Canada & 9 & 3 & $0.556(0.055)$ & $0.001(0.000)$ & 0.715 \\
\hline Iceland & 20 & 2 & $0.521(0.009)$ & $0.000(0.000)$ & 1.531 \\
\hline \multicolumn{6}{|l|}{ Greenland } \\
\hline Thule & 31 & 3 & $0.563(0.009)$ & $0.001(0.000)$ & -0.567 \\
\hline Kangerlussuaq & 16 & 5 & $0.667(0.028)$ & $0.001(0.000)$ & -0.545 \\
\hline Scoresbysund & 30 & 2 & $0.239(0.017)$ & $0.001(0.000)$ & -0.136 \\
\hline Maniitsoq & 6 & 4 & $0.800(0.070)$ & $0.001(0.000)$ & -1.367 \\
\hline \multicolumn{6}{|l|}{ Saker falcons } \\
\hline UAE & 20 & 11 & $0.868(0.014)$ & $0.005(0.000)$ & 0.812 \\
\hline
\end{tabular}

tAll values $P>0.05$.

(Table 4). In contrast, the majority of pairwise comparisons between sampling locations on Norway, Alaska and Canada were not significant, with the exception of that between Norway and Alaska possessing a low but significant $F_{\mathrm{ST}}$ value. Within Greenland, significant population structure was observed between eastern and western sampling locations (Scoresbysund vs. Thule \& Kangerlussuaq), while no significant differences were observed for the Scoresbysund and Kangerlussuaq populations when compared to Maniitsoq, a location sampled in southwestern Greenland during the winter migration period. Similarly, no differentiation was observed between the two western locations sampled during the breeding season (Thule \& Kangerlussuaq). In contrast to the microsatellite data, only the Iceland population showed significant mtDNA pairwise differences from the other gyrfalcon populations (Table 4). When each gyrfalcon population was compared to saker falcons collected in UAE, significant genetic subdivision $\left(F_{\mathrm{ST}}\right)$ was observed with both genetic markers in the majority of cases, with the exception of Maniitsoq, which was likely due to a low sample size in that population for this marker $(n=6$; Table 4$)$. 
Table 4 Pairwise population $F_{\mathrm{ST}}$ values for microsatellite (below the diagonal) and mtDNA (above the diagonal) analyses. Mitochondrial DNA data was not available for the Norway population. Significant values after correcting for multiple comparisons are indicated in bold and with asterisks

\begin{tabular}{|c|c|c|c|c|c|c|c|c|c|}
\hline & Thule & Scoresb. & Kanger. & Maniitsoq & Iceland & Canada & Alaska & Norway & Saker falcons \\
\hline Thule & - & 0.1233 & 0.0913 & 0.1060 & $0.2936^{* * *}$ & -0.0005 & -0.0006 & - & $0.4497^{* * *}$ \\
\hline Scoresbysund & $0.0447^{* *}$ & - & -0.0199 & -0.0482 & $0.2935^{* * *}$ & 0.2351 & 0.1605 & - & $0.4364^{* * *}$ \\
\hline Kangerlussuaq & 0.0322 & $0.0963^{* *}$ & - & -0.1169 & $0.2211^{* * *}$ & 0.0953 & 0.1314 & - & $0.3469^{* * *}$ \\
\hline Maniitsoq & $0.0385^{*}$ & 0.0232 & 0.0363 & - & 0.2520 & 0.0988 & 0.1481 & - & 0.2617 \\
\hline Iceland & $0.2176^{* * *}$ & $0.2505^{* * *}$ & $0.1454^{* * *}$ & $0.2072^{* * *}$ & - & $0.3314^{*}$ & $0.3105^{* * *}$ & - & $0.4225^{* * *}$ \\
\hline Canada & $0.1705^{* * *}$ & $0.1461^{* * *}$ & $0.0951^{*}$ & $0.0651^{*}$ & $0.2154^{* * *}$ & - & -0.0543 & - & $0.2967^{*}$ \\
\hline Alaska & $0.1033^{* * *}$ & $0.0970^{* * *}$ & $0.0865^{* * *}$ & $0.0528^{* * *}$ & $0.2362^{* * *}$ & 0.0478 & - & - & $0.3938^{* * *}$ \\
\hline Norway & $0.1357^{* * *}$ & $0.0928^{* * *}$ & $0.0813^{* *}$ & $0.0641^{* *}$ & $0.1950^{* * *}$ & 0.0580 & $0.0425^{*}$ & - & - \\
\hline Saker falcons & $0.2097^{* * *}$ & $0.2157^{* * *}$ & $0.1677^{* * *}$ & $0.1459^{* * *}$ & $0.1685^{* * *}$ & $0.1257^{* * *}$ & $0.1356^{* * *}$ & $0.1623^{* * *}$ & - \\
\hline
\end{tabular}

${ }^{*} P<0.01,{ }^{* *} P<0.001,{ }^{* * *} P<0.0001$.

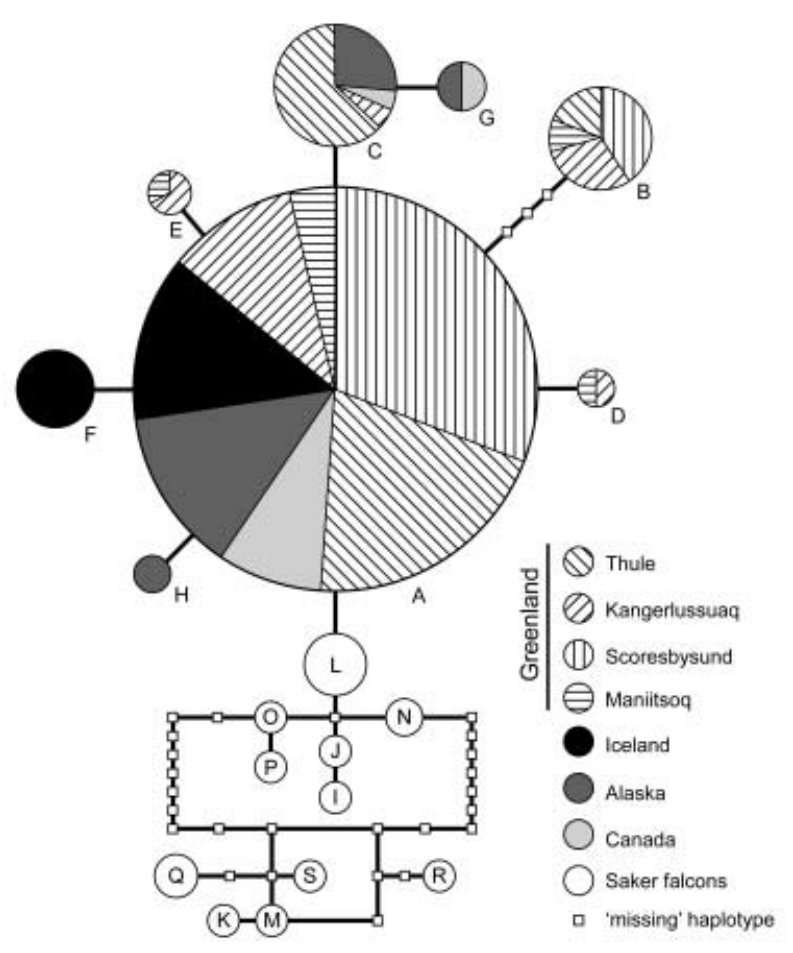

Fig. 2 Parsimony network based on gyrfalcon and saker falcon mtDNA haplotypes, lettered A through S. Each circle represents a single haplotype where the size of the circle corresponds to the number of individuals observed with that particular haplotype. Solid lines represent most parsimonious connections between haplotypes with a probability higher than $95 \%$. Each connection between haplotypes corresponds to a single point-mutation, and open squares represent intermediate haplotypes 'missing' in the sample but necessary to make connections between sampled haplotypes.

Little variability in the mtDNA sequence data was observed among gyrfalcon samples with haplotypes forming a starlike pattern in the parsimony network (Fig. 2). A few haplotypes were unique to particular geo-

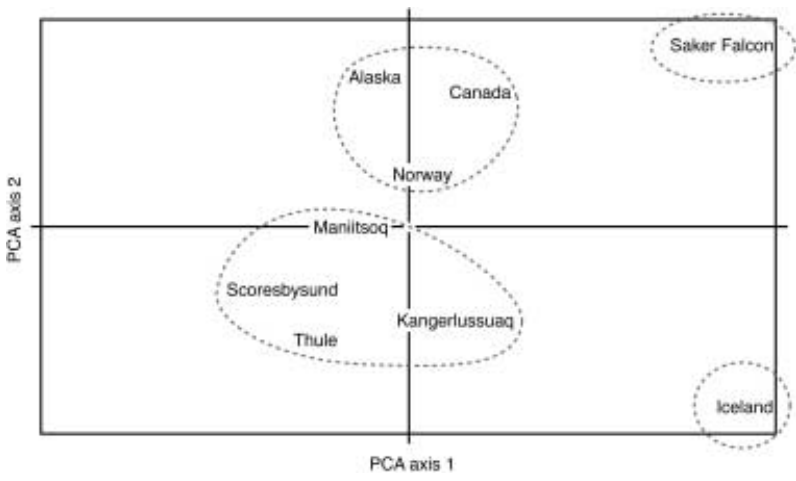

Fig. 3 PCA showing the genetic relationships among gyrfalcon and saker falcon sampling locations. PCA axis 1 explains $44.6 \%$ $(P=0.01)$ of the variance and PCA axis 2 explains $26.6 \%(P=0.03)$. PCA axes $3 \& 4$ (not shown) explain $12.2 \%(P>0.05)$ and $7.0 \%$ $(P>0.05)$ of the variance, respectively. Locations within each dotted ellipse represent identified population clusters from STRUCTURE (see Fig. 4).

graphic locations, yet these haplotypes differed by only one to four nucleotides from a common haplotype shared by all gyrfalcon sample locations. For saker falcons, two haplotype clusters were observed and separated by at least 12 nonsampled fixed nucleotide steps in the network. In one of these clusters, seven saker falcons had a haplotype (L) that differed by a single nucleotide position from the most common gyrfalcon haplotype (A; see Fig. 2).

Principal component analysis (PCA) using the microsatellite data showed a clear separation between gyrfalcons and saker falcons, and between Iceland and other gyrfalcon sampling locations (Fig. 3). Two clusters were observed among the remaining sample locations, with Greenland forming a single cluster and Alaska, Canada and Norway forming a second cluster. A location sampled during the winter nonbreeding period in Greenland (i.e. Maniitsoq) was intermediate between these two clusters in the PCA. Population 


\begin{tabular}{|c|c|c|c|c|}
\hline \multirow[b]{2}{*}{ Sampling location } & \multicolumn{4}{|c|}{ Proportion of membership (for $K=4$ ) } \\
\hline & Cluster 1 & Cluster 2 & Cluster 3 & Cluster 4 \\
\hline Thule & 0.011 & 0.924 & 0.031 & 0.034 \\
\hline Scoresbysund & 0.015 & 0.855 & 0.047 & 0.083 \\
\hline Kangerlussuaq & 0.024 & 0.703 & 0.154 & 0.119 \\
\hline Maniitsoq & 0.039 & 0.771 & 0.023 & 0.167 \\
\hline Iceland & 0.043 & 0.080 & 0.853 & 0.023 \\
\hline Canada & 0.056 & 0.206 & 0.050 & 0.689 \\
\hline Alaska & 0.062 & 0.247 & 0.028 & 0.663 \\
\hline Norway & 0.077 & 0.234 & 0.072 & 0.617 \\
\hline Saker falcons & 0.867 & 0.057 & 0.030 & 0.047 \\
\hline
\end{tabular}

Table 5 Proportion of membership for each sampling location to each cluster $(K=4)$ using the program STRUCTURE. Boxes represent clustered populations. Average likelihood values for $K=1$ through 6 over four independent runs were $-3286.0,-3056.8,-2985.0,-2899.3$, -3040.4 , and -2955.8 , respectively

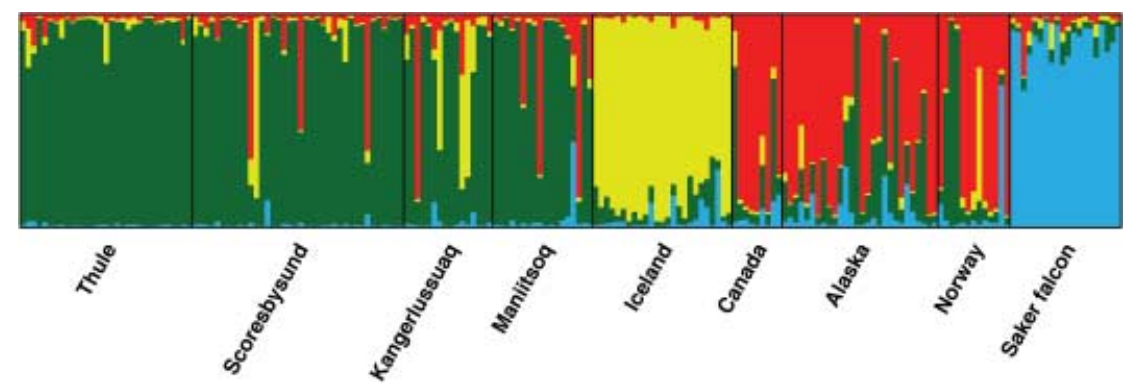

Fig. 4 Assignment of individual falcons using STRUCTURE based on sample location and $K=4$. Colors correspond to one of four population clusters indicated in Table 5. Each bar represents a single individual sample and presented in groups based on sampling location.

scores were plotted on two principal axes (PC1 and PC2), which cumulatively explained $71.2 \%$ of the total genetic diversity (PC1: 44.6\%, $P=0.01$, PC2: $26.6 \%, P=0.03$; Fig. 3).

Four population clusters $(K=4)$ were identified using the program STRUCTURE (Table 5). Both Iceland gyrfalcons and saker falcons had comparable high assignment proportions ( $85 \%$ \& $87 \%$, respectively) in separate clusters, with few individuals identified with mixed ancestry (Fig. 4). All Greenland sample locations, including Maniitsoq, clustered together with relatively high assignment proportions (70$92 \%)$, with low assignment proportions also for Alaska, Canada, and Norway (21-25\%) in this same cluster (Table 5). The fourth cluster consisted of individuals from Alaska $(66 \%)$, Canada (69\%), and Norway (62\%), with diminutive assignment proportions (3-17\%) also identified for Greenland in this cluster.

\section{Migration rates}

Based on estimates from BAYESASS, recent immigration rates among the majority of sampled locations are quite low $(m<0.03)$ with a high proportion of individuals derived from their own population (>0.95; Table 6), suggesting that most areas are isolated from each other, at least with respect to first- and second-generation immigrants (see Wilson \& Rannala 2003). Within Greenland, however, we do observe two cases with relatively high proportions of immigrants ( $m=0.24$ ) between sampling locations, both of which are significantly different from zero. This movement appears asymmetric with birds from Thule, in northwest Greenland, immigrating into both the Scoresbysund and Kangerlussuaq populations in northeast and central-west Greenland, respectively, with essentially no movement $(m<0.005)$ indicated in the opposite direction for both cases (Table 6). Immigration rates between Scoresbysund and Kangerlussuaq are low $(m=0.004 \& 0.027)$ with lower $95 \%$ confidence intervals essentially zero $(<0.000)$ for both directions.

\section{Discussion}

Significant population genetic structure exists between the two island gyrfalcon populations (i.e. Greenland \& Iceland) and between each of these two islands and the mainland regions (i.e. Canada, Alaska \& Norway); however, the extent of this genetic differentiation varies based on the type of genetic marker (microsatellite or mtDNA) and the particular method used to discern this differentiation. The ability to identify and define biological 'populations' is crucial for making informed decisions concerning conservation and management (Waples \& Gaggiotti 2006), and the recognition of particular limitations associated with methods used to describe populations has important implications (Neigel 2002; Pearse \& Crandall 2004; Manel et al. 2005; Palsbøll et al. 2007). 
Table 6 Migration rates among gyrfalcon populations using the program BAYESASs. Values shown are the means of the posterior distributions of $m$, the migration rate into each population, and their respective $95 \%$ confidence intervals in parentheses. Values along the diagonal (in bold) are the proportion of individuals derived from the source population each generation. Migration rates greater than 0.100 are underlined. CA/AK, Canada and Alaska combined into a single population

\begin{tabular}{|c|c|c|c|c|c|c|}
\hline \multirow[b]{2}{*}{ Migration into } & \multicolumn{6}{|c|}{ Migration from } \\
\hline & Thule & Scoresb. & Kanger. & Iceland & $\mathrm{CA} / \mathrm{AK}$ & Norway \\
\hline Thule & $\begin{array}{l}0.985 \\
(0.947-1.000)\end{array}$ & $\begin{array}{l}0.005 \\
(0.000-0.032)\end{array}$ & $\begin{array}{l}0.002 \\
(0.000-0.016)\end{array}$ & $\begin{array}{l}0.003 \\
(0.000-0.017)\end{array}$ & $\begin{array}{l}0.003 \\
(0.000-0.019)\end{array}$ & $\begin{array}{l}0.003 \\
(0.000-0.015)\end{array}$ \\
\hline Scoresbysund & $\frac{0.241}{(0.159-0.308)}$ & $\begin{array}{l}0.737 \\
(0.677-0.816)\end{array}$ & $\begin{array}{l}0.004 \\
(0.000-0.022)\end{array}$ & $\begin{array}{l}0.007 \\
(0.000-0.032)\end{array}$ & $\begin{array}{l}0.006 \\
(0.000-0.028)\end{array}$ & $\begin{array}{l}0.005 \\
(0.000-0.026)\end{array}$ \\
\hline Kangerlussuaq & $\frac{0.244}{(0.147-0.316)}$ & $\begin{array}{l}0.027 \\
(0.000-0.097)\end{array}$ & $\begin{array}{l}0.686 \\
(0.667-0.733)\end{array}$ & $\begin{array}{l}0.016 \\
(0.000-0.076)\end{array}$ & $\begin{array}{l}0.016 \\
(0.000-0.074)\end{array}$ & $\begin{array}{l}0.011 \\
(0.000-0.058)\end{array}$ \\
\hline Iceland & $\begin{array}{l}0.003 \\
(0.000-0.019)\end{array}$ & $\begin{array}{l}0.003 \\
(0.000-0.020)\end{array}$ & $\begin{array}{l}0.003 \\
(0.000-0.018)\end{array}$ & $\begin{array}{l}0.985 \\
(0.948-1.000)\end{array}$ & $\begin{array}{l}0.003 \\
(0.000-0.020)\end{array}$ & $\begin{array}{l}0.003 \\
(0.000-0.019)\end{array}$ \\
\hline $\mathrm{CA} / \mathrm{AK}$ & $\begin{array}{l}0.011 \\
(0.000-0.053)\end{array}$ & $\begin{array}{l}0.005 \\
(0.000-0.028)\end{array}$ & $\begin{array}{l}0.007 \\
(0.000-0.031)\end{array}$ & $\begin{array}{l}0.004 \\
(0.000-0.024)\end{array}$ & $\begin{array}{l}0.966 \\
(0.906-0.997)\end{array}$ & $\begin{array}{l}0.007 \\
(0.000-0.036)\end{array}$ \\
\hline Norway & $\begin{array}{l}0.007 \\
(0.000-0.042)\end{array}$ & $\begin{array}{l}0.011 \\
(0.000-0.067)\end{array}$ & $\begin{array}{l}0.007 \\
(0.000-0.043)\end{array}$ & $\begin{array}{l}0.008 \\
(0.000-0.050)\end{array}$ & $\begin{array}{l}0.021 \\
(0.000-0.177)\end{array}$ & $\begin{array}{l}0.946 \\
(0.774-0.999)\end{array}$ \\
\hline
\end{tabular}

\section{Population structure}

While the microsatellite data do suggest significant genetic structure differences between Greenland and Iceland populations relative to all sampled mainland gyrfalcon populations (Canada, Alaska \& Norway; Tables 4-6), only Iceland is distinct based on the $F_{\mathrm{ST}}$ analyses of the mtDNA (Table 4). This difference in inference based on different genetic markers could be due to either sex-biased dispersal with females dispersing further than males (e.g. Piertney et al. 2000) or lack of resolution and retention of ancestral polymorphisms through incomplete lineage sorting (e.g. Omland et al. 2006) limiting the power to detect population structure with the mtDNA marker used in this study (Taylor \& Dizon 1996; Bossart \& Prowell 1998). With this data set, the latter scenario seems more probable because genetic differentiation was observed between areas separated by obvious dispersal barriers (i.e. oceans) despite the low mtDNA variability observed among all gyrfalcons (see also Roques \& Negro 2005; Brown et al. 2007). A single mtDNA haplotype was found in high frequency among all sampled areas, and the remaining seven haplotypes differed from this common haplotype by one to four nucleotide substitutions (Fig. 2, Table 2). A number of these less common haplotypes, however, were unique to particular geographic areas such as Greenland and Iceland suggesting that dispersal is limited between these areas.

Within Iceland a large percentage of adult gyrfalcons are known to occupy their breeding territories year-round with no evidence suggesting dispersal outside of Iceland (Nielsen 1986; Nielsen \& Cade 1990a; Cade et al. 1998; Potapov $\&$ Sale 2005). White colour variants have been recorded during the winter in Iceland; however, these birds most likely are migrants from Greenland as the only gyrfalcons observed breeding in Iceland are grey to light grey in colour (Pétursson et al. 1993; Ó. Nielson, personal communication). Indeed, a juvenile female white gyrfalcon trapped in Scoresbysund and fitted with a satellite transmitter was documented travelling to Iceland during winter migration, then returning to the Scoresbysund area in the spring, as it continued its migration north along the coast of northeast Greenland (K. Burnham, unpublished data). These observations agree with our genetic results with both markers indicating that the population of gyrfalcons on Iceland shows significant differentiation from all other populations.

Similarly, the sampled locations in Greenland, when compared to all other areas, were significantly different based on the microsatellite data. The limited dispersal data for gyrfalcons in Greenland based on ringing efforts and satellite telemetry suggest that gyrfalcons migrate to the southern end of the island during winter (Potapov \& Sale 2005; K. Burnham, unpublished data). Occasionally, Greenland gyrfalcons also migrate to Iceland (see above), but these individuals do not appear to breed in Iceland given our genetic results. Potapov \& Sale (2005) have also suggested based on plumage colour that 'grey' gyrfalcons wintering in the Faeroes and British Isles likely originated from Greenland; however, there is no evidence to support this claim as these birds could have also migrated from Iceland or Fennoscandia based on plumage colouration alone. The program STRUCTURE does suggest some admixture between Greenland and Norway (Fig. 4; Table 5); although, no recent migration events were indicated between these two areas by BAYESASs (Table 6). Additional samples from Fennoscandia will help clarify these relationships as the Norwegian population was represented by a relatively small sample $(n=13$; see below). 
Individuals with satellite transmitters have also been documented migrating from around Maniitsoq in Greenland to Canada and Thule (K. Burnham, unpublished data). Therefore, it is not surprising to see the gyrfalcons sampled from Maniitsoq during the fall migration period to be intermediate between breeding populations of these two areas in the PCA (Fig. 3; also including Alaska \& Norway) and to include individuals with mixed ancestry or relatively high assignment probabilities to other areas (Fig. 4). However, despite these similarities, if recent immigration does occur between Greenland and Canada, it is not sufficient to be shown here, as breeding populations within Greenland are significantly different relative to all other sampled areas based on our microsatellite DNA analyses using $F_{\mathrm{ST}}$ (Table 4) and the program BAYESASS (Table 6) suggesting high breeding-site fidelity for these two areas. It would be worthwhile to investigate potential connectivity between Greenland and northeast Canada with additional samples from Baffin and Ellesmere Islands because the Canada samples used in this study were from central north Canada $\left(63^{\circ} \mathrm{N}, 104^{\circ} \mathrm{W}\right)$.

Within Greenland, significant genetic differentiation $\left(F_{\mathrm{ST}}\right)$ was observed between western (Thule \& Kangerlussuaq) and northeastern (Scoresbysund) regions based on the microsatellite data. In the extreme northwest, or around Thule, most of the juvenile and adult gyrfalcons observed ( $n=170$ birds) during the breeding seasons between 1993 and 2005 were white in plumage (>99\%), while further south in central west Greenland near Kangerlussuaq adult gyrfalcons $(n=112)$ observed between 1998 and 2005 breeding seasons were white $(52 \%)$ to off-white or silver $(13 \%)$ to grey $(36 \%)$ with a few dark grey individuals also observed (K. Burnham, unpublished data; see also Potapov \& Sale 2005). In east Greenland in Scoresbysund, birds trapped $(n=119)$ during fall migration in 2004 and 2005 were predominately white in colour, similar to Thule, with a few grey gyrfalcons ( 2\%) also observed (K. Burnham, unpublished data). As such, the distributions of colour variants appear to reflect a reduced level of connectivity with other sampled populations outside of Greenland, with the north (Thule \& Scoresbysund) appearing more isolated than that observed further south. For example, Kangerlussuaq, although significantly different, had lower levels of population differentiation $\left(F_{\mathrm{ST}}\right.$; Table 4$)$ with Canada and Alaska, all of which have similar colour variants relative to Thule or Scoresbysund in the north.

This relationship between the distribution of colour variants and levels of genetic differentiation within Greenland was also reflected in our results from the programs STRUCTURE and BAYESASS. Both of these methods suggest that northern Greenland, particularly Thule, is more isolated relative to central-west Greenland, and analyses with STRUCTURE indicate low levels of gene flow between Kangerlussuaq and the Alaska, Canada, and Norway cluster (Fig. 4). Fewer individuals sampled in northern Greenland were identified with mixed ancestry, indicating a possible dispersal bias or a source-sink relationship. This is further supported by our results from the program BAYESASS, suggesting asymmetric migration with gyrfalcons from the Thule population dispersing south to Kangerlussuaq and not in the opposite direction. In contrast with our $F_{\mathrm{ST}}$ analysis, relatively high migration from Thule to Scoresbysund was indicated using BAYESASS. We cannot discern with our sampling whether this connectivity is around the icecap from the north or the south, and it is not known whether gyrfalcons disperse across the icecap. Given that we did not identify recent migration between Scoresbysund and Kangerlussuaq using BAYESASS, suggests that connectivity between Thule and Scoresbysund may be around the icecap to the north instead of the south. Gyrfalcons are known to breed in the extreme north in Peary Land within Greenland (Koch 1925; Johnsen 1953) and this could provide the connectivity between these two areas as shown with our genetic results.

Outside of Greenland and Iceland, little geographic structure was observed. Gene flow between Alaska and Canada is not surprising given the presence of contiguous nesting habitat throughout this region and the lack of obvious dispersal barriers. The suggested genetic connectivity between these two areas with those in Norway, however, was unexpected because of the large geographic distance separating these areas. Data do exist, however, based on satellite telemetry identifying birds in Alaska migrating into Russia during the winter (C. McIntyre, unpublished data; see also del Hoyo et al. 1994, pg. 237); although, we do not know whether any gyrfalcons from Alaska remain in Russia to breed, or vise versa.

The absence of significant genetic differentiation between Norway and both Alaska and Canada sample locations does not necessarily imply contemporary gene flow, as multiple explanations for homogeneity are possible (Taylor \& Dizon 1996; Bossart \& Prowell 1998; Waples \& Gaggiotti 2006; Palsbøll et al. 2007). For example, sample size, number of loci, and amount of genetic polymorphism among loci can have a strong effect on the results from assignment-based methods such as those incorporated in the program STRUCTURE (Manel et al. 2005; Waples \& Gaggiotti 2006). Depending on the particular assignment method and the sample sizes, reasonable assignment success is associated with a minimal level of differentiation with performance decreasing as $F_{\mathrm{ST}}$ decreases (Berry et al. 2004; Hauser et al. 2006; Latch et al. 2006; Waples \& Gaggiotti 2006). In addition, the ability to detect migrants between populations is greatest when populations are genetically divergent; however, in such cases, gene flow is relatively rare and therefore difficult to detect unless the actual migrants or their direct descendents are sampled. Results from BAYESASs suggest no recent migration between Norway and Alaska/Canada, although this method assumes that all populations that are exchanging migrants have been sampled (Wilson \& Rannala 2003). 
Therefore, given the large geographic distance between Norway and Alaska, unsampled 'ghost' populations may have influenced our estimates of migration rates (see Slatkin 2005), and more samples from Fennoscandia and particularly Siberia are required to further investigate gene flow between these two widely distributed geographic areas. Similarly, it would also be worthwhile to obtain samples from southeast Greenland to further investigate the connectivity around the southern portion of the island.

\section{Demographic history}

The presence of geographic structure among gyrfalcon populations, particularly for the Greenland and Iceland populations, corresponds to general phylogeographic patterns observed among a number of codistributed arctic and subarctic taxa. These include lemmings (Dicrostonyx spp., Fedorov \& Goropashnaya 1999; Fedorov \& Stenseth 2002), rock ptarmigan (Lagopus mutus; Holder et al. 1999), root vole (Microtus oeconomus; Brunhoff et al. 2003), and arctic hares (Lepus spp.; Waltari et al. 2004; Waltari \& Cook 2005), all of which also serve as the primary prey of gyrfalcons (Muir \& Bird 1984; Nielsen \& Cade 1990b; Cade et al. 1998; Booms \& Fuller 2003; Nyström et al. 2006). Although there is evidence among mtDNA haplotype groups or clusters in the above taxa that current geographic distributions were influenced by multiple glacial refugia, the mtDNA data in this study do not support a historical association with multiple refugia for gyrfalcons. The starlike pattern observed in the haplotype network (Fig. 2) and the overall low variability of mtDNA do, however, suggest a recent expansion from a single small glacialage population (Slatkin \& Hudson 1991; Neigel 2002). If so, the local differentiation reported here likely developed via drift and strong philopatry, reinforced by barriers to dispersal (e.g. large bodies of water between Greenland, Iceland, \& the mainland) as indicated by our microsatellite data. This pattern has also been observed with other arctic taxa such as walrus (Odobenus rosmarus, Andersen et al. 1998), rock ptarmigan (Lagopus mutus, Holder et al. 1999), polar bear (Ursus maritimus, Paetkau et al. 1999), and muskoxen (Ovibos moschatus, Van Coeverden de Groot 2001).

Similarly, in a recent study on the pink-footed goose, Anser brachyrhynchus, Ruokonen et al. (2005) proposed that despite evidence suggesting minimal contemporary connectivity between populations based on ringing data, low levels of mtDNA haplotype diversity $(h)$ in Iceland and Greenland were an indication of a recent colonization event within the last 2500 years from an eastern population (Svalbard) in the north Atlantic that had much higher levels $(5 \times)$ of mtDNA variability. They do not discount the possibility of historic glacial refugia for this species in Iceland or Greenland, but they do suggest that given their relatively high estimates of long-term female effective population size (5400-7700), northern refugia alone are unlikely to have played a significant role for this species and that the expansion from much larger areas in the south is a more likely explanation (see also Bennike 1999).

Gyrfalcon populations in Iceland and Greenland, with the exception of the Scoresbysund sampling location, have levels of mtDNA haplotype diversity comparable to our other sampled areas (Table 3), and, likewise, all sampled locations, including Scoresbysund, had similar levels of microsatellite diversity (Table 1 ). These results argue against a recent expansion into Greenland and Iceland from an older population of much larger size (see Hewitt 1999; Nichols et al. 2001; Hewitt \& Nichols 2005). Given the low haplotype and nucleotide diversity in all surveyed gyrfalcon locations, however, a rapid expansion to all contemporary locations from a small founder population cannot be discounted (e.g. Buehler \& Baker 2005).

When gyrfalcons were compared to a close relative, the saker falcon, higher levels of both mtDNA and microsatellite diversity estimates were observed in the saker falcon population. A number of historic demographic scenarios may have been responsible for this difference between these taxa. Multiple mtDNA clades for saker falcons have been identified that do not correspond to geography (Nittinger et al. 2005, 2007), and sister relationships among gyrfalcons and saker, lanner (Falco biarmicus), and lagger (Falco jugger) falcons remain unresolved (Wink et al. 2004; Nittinger et al. 2005, 2007). Among these taxa, Nittinger et al. $(2005,2007)$ documented no shared mtDNA control region haplotypes with the exception of a single common haplotype observed among all four falcon species and a less frequent haplotype observed between lagger falcons and gyrfalcons. As suggested by Nittinger et al. $(2005,2007)$, ancestral saker falcon and gyrfalcon populations could have existed in separate glacial refugia and subsequently hybridized when the distribution of both species expanded following the end of the last glacial period.

In this study, we did not identify any shared haplotypes between saker falcons and gyrfalcons. This inconsistency between studies could be due to differences in sequence length as Nittinger $e t$ al. $(2005,2007)$ used a smaller section of the mtDNA control region (412-418 bp) than used in this study (1540 bp), and we also observed a fixed nucleotide difference between taxa within cytb (Table 3; see also Wink et al. 2004), a mtDNA region that was not included in the Nittinger et al. studies. Therefore, it seems more likely based on our results that two ancestral saker falcon populations once existed, possibly in separate glacial refugia, and introgression occurred following glacial retreat (see also Hofreiter et al. 2004; Weir \& Schluter 2004). Following this scenario, gyrfalcons could have originated recently through a small founder event from an ancestor of one of these populations prior to their intermixing, given that only a single cluster of haplotypes have been observed among gyrfalcons. 
Although we cannot determine which of the above scenarios is correct because of differences in sampling between studies, they both do suggest that gyrfalcons expanded rapidly from a single population during the late Pleistocene to occupy their current circumpolar distribution. Gyrfalcon fossils have been described from the late Pleistocene in both southern Europe (Tyrberg 1998) and western United States (Emslie 1985) consistent with both of these demographic scenarios. Further, an extinct falcon (Falco antiquus) and proposed common ancestor of gyrfalcons and saker falcons has been described from the late middle Pleistocene in southern Europe, where it is thought to have originated and expanded eastward through Asia into North America (Potapov \& Sale 2005). A more thorough sampling of all representative taxa in this group including additional methodological approaches is necessary to better ascertain the evolutionary relationships among these falcons.

\section{Conclusions}

Gyrfalcons inhabit a harsh and extreme environment making research on their life history difficult. By utilizing genetic methods, we were able to investigate population level connectivity that would have been difficult to determine at the same scale using more traditional methods such as banding records or telemetry. The majority of historic taxonomic designations (five to seven subspecies) based on plumage colour and geography (cf. Vaurie 1961) are not supported by our genetic results. We do find support, however, for distinctive Greenland and Iceland gyrfalcon populations, both of which had a higher frequency of single colour variants, whereas minimal genetic differentiation between Norway, Alaska and Canada was observed suggesting a single large population among the latter three sampled locations. Within Greenland, the observed asymmetrical dispersal from Thule to Kangerlussuaq would allow local adaptation, and the high proportion of white gyrfalcons observed in northern Greenland may be due to a selective advantage for this plumage colour. Whether this difference is associated with differences in prey preference (e.g. Dalén et al. 2005), the result of physiological constraints (e.g. Potapov \& Sale 2005), or from genetic drift deserves more attention (see also Storz 2005; Cade 2006; Gray \& McKinnon 2007). This information should prove useful for conservation as recent abundance estimates in Greenland suggest that gyrfalcons are in decline, while the number of peregrine falcons (Falco peregrinus) has increased and expanded northward into areas where it has been previously undocumented (K. Burnham, unpublished data; see also Hitch \& Leberg 2007). Therefore, as climate change increases, the viability of gyrfalcon populations may be of concern (Berteaux et al. 2004; Callaghan et al. 2004; Hewitt \& Nichols 2005), with changes in their distributions and genetic variability providing early warnings of climate change and its influence on arctic biodiversity.

\section{Acknowledgements}

This research was made possible with the help of many individuals and organizations. We would particularly like to thank B. and R. Mutch, J. Cafferty, J. Stephens, B. Heinrich, C. Sandfort, J. Willmarth, E. Gott, and R. Haswell for assistance in collecting samples in Greenland. We thank Ó. Nielsen and the Ministry for the Environment for assistance in Iceland, C. Cyrus for help obtaining samples from Alaska, M. Nesje and J. Lifjeld for microsatellite data from Norway, and M. Gabriele Muller from the Abu Dhabi Falcon Hospital for saker falcon samples. We also thank the falconers in Alaska who generously provided tissue samples from their own wild-taken birds. W. Grus and M. Klaver provided assistance in the laboratory, and T. Cade, G. Hewitt, and three anonymous reviewers provided helpful comments on the manuscript. Work in Greenland is in cooperation with and authorized by the Commission for Scientific Research in Greenland, Greenland Home Rule Government, the Danish Polar Center, and the US Air Force. In Alaska, our activities were authorized by the Alaska Department of Fish and Game with special assistance from K. Titus and W. Regelin. We thank the residents of Thule Air Base, the 109th Air National Guard, National Science Foundation, VECO Polar Associates and R. Abbott, E. Stockard, T. Quinn, E. Vaughn, and S. Zager. Additional thanks to B. Brodersen, B. Vængtoft, and K. Bahr Friis of KISS. Financial support was provided by The Peregrine Fund through donations made by R. Mutch, P. Pfendler, R. Wasendorf, J. Stephens, Gordon and Betty Moore Foundation, The Charles Engelhard Foundation, Bennu and the Florence Hegyi Family Trust.

\section{References}

Andersen LW, Born EW, Gjertz I, Wiig Ø, Holm L-E, Bendixen C (1998) Population structure and gene flow of the Atlantic walrus (Odobenus rosmarus rosmarus) in the eastern Atlantic Arctic based on mitochondrial DNA and microsatellite variation. Molecular Ecology, 7, 1323-1336.

Anne C (2006) Choosing the right molecular genetic markers for studying biodiversity: from molecular evolution to practical aspects. Genetica, 127, 101-120.

Bennike O (1999) Colonisation of Greenland by plants and animals after the last ice age: a review. Polar Record, 35, 323-336.

Berry O, Tocher MD, Sarre SD (2004) Can assignment tests measure dispersal? Molecular Ecology, 13, 551-561.

Berteaux D, Réale D, McAdam AG, Boutin S (2004) Keeping pace with fast climate change: can arctic life count on evolution? Integrative and Comparative Biology, 44, 140-151.

Booms TL, Fuller MR (2003) Gyrfalcon diet in central west Greenland during the nesting period. The Condor, 105, 528-537.

Bossart JL, Prowell DP (1998) Genetic estimates of population structure and gene flow: limitations, lessons, and new directions. Trends in Ecology \& Evolution, 13, 202-206.

Brown JW, Van Coeverden de Groot PJ, Birt TP, Seutin G, Boag PT, Friesen VL (2007) Appraisal of the consequences of the DDTinduced bottleneck on the level and geographic distribution of neutral genetic variation in Canadian peregrine falcons, Falco peregrinus. Molecular Ecology, 16, 327-344.

Brunhoff C, Galbreath KE, Fedorov VB, Cook JA, Jaarola M (2003) Holarctic phylogeography of the root vole (Microtus oeconomus): 
implications for late Quaternary biogeography of high latitudes. Molecular Ecology, 12, 957-968.

Buehler DM, Baker AJ (2005) Population divergence times and historical demography in red knots and dunlins. The Condor, 107, 497-513.

Cade TJ (1982) Falcons of the World. William Collins Sons \& Co. Limited, London, UK.

Cade TJ (2006) The gyrfalcon. The Auk, 123, 920-923.

Cade TJ, Koskimies P, Nielsen O (1998) Falco rusticolus Gyrfalcon. In: Birds of the Western Palearctic Update, Vol. 2, No. 1 (ed. Cramp S), pp. 1-25. Oxford University Press, Oxford, UK.

Callaghan TV, Björn LO, Chernov Y et al. (2004) Effects on the structure of arctic ecosystems in the short- and long-term perspectives. Ambio, 33, 436-447.

Clement M, Posada E, Crandall KA (2000) TCS: a computer program to estimate gene genealogies. Molecular Ecology, 9, 1657-1659.

Dalén L, Fuglei E, Hersteinsson P et al. (2005) Population history and genetic structure of a circumpolar species: the arctic fox. Biological Journal of the Linnean Society, 84, 79-89.

DeYoung RW, Honeycutt RL (2005) The molecular toolbox: genetic techniques in wildlife ecology and management. Journal of Wildlife Management, 69, 1362-1384.

Emslie SD (1985) The late Pleistocene (Rancholabrean) avifauna of Little Box Elder Cave, Wyoming. Contributions to Geology, 23, 63-82.

Excoffier L, Laval G, Schneider S (2005) ARLEQUIN version 3.0: an integrated software package for population genetics data analysis. Evolutionary Bioinformatics Online, 1, 47-50.

Falush D, Stephens M, Pritchard JK (2003) Inference of population structure using multilocus genotype data: linked loci and correlated allele frequencies. Genetics, 164, 1567-1587.

Fedorov VB, Goropashnaya AV (1999) The importance of ice ages in diversification of Arctic collared lemmings (Dicrostonyx): evidence from the mitochondrial cytochrome $b$ region. Hereditas, 130, 301-307.

Fedorov VB, Stenseth NC (2002) Multiple glacial refugia in the North American Arctic: inference from phylogeography of the collared lemming (Dicrostonyx groenlandicus). Proceedings of the Royal Society of London. Series B, Biological Sciences, 269, 2071-2077.

Ferguson-Lees J, Christie DA (2001) Raptors of the World. Christopher Helm, London, UK.

Flann I (2003) Gyrfalcon color variation. Journal of Raptor Research, $37,173-174$.

Goodman SJ (1997) RSTCALC, a collection of computer programs for calculating estimates of genetic differentiation from microsatellite data and determining their significance. Molecular Ecology, 6, 881-885.

Goudet J (1995) FSTAT (version 1.2): a computer program to calculate F-statistics. Journal of Heredity, 86, 485-486.

Gray SM, McKinnon JS (2007) Linking color polymorphism maintenance and speciation. Trends in Ecology \& Evolution, 22, 71-79.

Hauser L, Seamons TR, Dauer M, Naish KA, Quinn TP (2006) An empirical verification of population assignment methods by marking and parentage data: hatchery and wild steelhead (Oncorhynchus mykiss) in Forks Creek, Washington, USA. Molecular Ecology, 15, 3157-3173.

Hewitt GM (1996) Some genetic consequences of ice ages, and their role in divergence and speciation. Biological Journal of the Linnean Society, 58, 247-276.

Hewitt GM (1999) Post-glacial re-colonization of European biota. Biological Journal of the Linnean Society, 68, 87-112.

Hewitt GM (2004) The structure of biodiversity-insights from molecular phylogeography. Frontiers in Zoology, 1, 4.
Hewitt GM, Nichols RA (2005) Genetic and evolutionary impacts of climate change. In: Climate Change and Biodiversity (eds Lovejoy TE, Hannah L), pp. 176-192. Yale University Press, New Haven, Connecticut.

Hitch AT, Leberg PL (2007) Breeding distributions of North American bird species moving north as a result of climate change. Conservation Biology, 21, 534-539.

Hofreiter M, Serre D, Rohland N et al. (2004) Lack of phylogeography in European mammals before the last glaciation. Proceedings of the National Academy of Sciences, USA, 101, 12963-12968.

Holder K, Montgomerie R, Friesen VL (1999) A test of the glacial refugium hypothesis using patterns of mitochondrial and nuclear DNA sequence variation in Rock Ptarmigan (Lagopus mutus). Evolution, 53, 1936-1950.

del Hoyo J, Elliot A, Sargatal J, eds (1994) Handbook of the Birds of the World, Vol. 2. New World Vultures to Guineafowl. Lynx Edicions, Barcelona, Spain.

Johnsen P (1953) Birds and mammals of Peary Land in North Greenland. Meddelelser om Grønland, 128, 1-138.

Kinnison MT, Bentzen P, Unwin MJ, Quinn TP (2002) Reconstructing recent divergence: evaluating nonequilibrium population structure in New Zealand chinook salmon. Molecular Ecology, 11, 739-754.

Koch L (1925) Nord om Grønland. Køvenhavn, Denmark.

Latch EK, Dharmarajan G, Glaubitz JC, Rodes OE (2006) Relative performance of Bayesian clustering software for inferring population substructure and individual assignment at low levels of population differentiation. Conservation Genetics, 7, 295-302.

Leberg PL (2002) Estimating allelic richness: effects of sample size and bottlenecks. Molecular Ecology, 11, 2445-2449.

Lewis PO, Zaykin D (2001) GENETIC DATA ANALYSIS: Computer Program for the Analysis of Allelic Data, Version 1.0 (d16c). University of Connecticut, Storrs, Connecticut.

Manel S, Gaggiotti OE, Waples RS (2005) Assignment methods: matching biological questions with appropriate techniques. Trends in Ecology \& Evolution, 20, 136-142.

Mindell DP, Sorenson MD, Dimcheff DE, Hasegawa M, Ast JC, Yuri T (1999) Interordinal relationships of birds and other reptiles based on whole mitochondrial genomes. Systematic Biology, 48, 138-152.

Muir D, Bird DM (1984) Food of gyrfalcons at a nest on Ellesmere Island. The Wilson Bulletin, 96, 464-467.

Neigel JE (2002) Is $F_{\mathrm{ST}}$ obsolete? Conservation Genetics, 3, 167-173.

Nesje M, Røed KH (2000) Microsatellite DNA markers from the Gyrfalcon (Falco rusticolus) and their use in other raptor species. Molecular Ecology, 9, 1433-1449.

Nesje M, Røed KH, Lifjeld JT, Lindberg P, Steens OF (2000) Genetic relationship in the peregrine falcon (Falco peregrinus) analyzed by microsatellite DNA markers. Molecular Ecology, 9, 53-60.

Newton I (2003) Speciation and Biogeography of Birds. Academic Press, London, UK.

Nichols RA, Bruford MW, Groombridge JJ (2001) Sustaining genetic variation in a small population: evidence from the Mauritius kestrel. Molecular Ecology, 10, 593-602.

Nielsen ÓK (1986) Population Ecology of the Gyrfalcon in Iceland, with Comparative Notes on the Merlin and Raven. PhD Thesis, Cornell University, Ithaca, New York.

Nielsen ÓK, Cade TJ (1990b) Seasonal changes in food habits of gyrfalcon in NE-Iceland. ORNIS Scandinavica, 21, 202-211.

Nielsen ÓK, Cade TJ (1990a) Annual cycle of the Gyrfalcon in Iceland. National Geographic Research, 6, 41-62.

Nittinger F, Haring E, Pinsker W, Wink M, Gamauf A (2005) Out of Africa? Phylogenetic relationships between Falco biarmicus 
and the other hierofalcons (Aves: Falconidae). Journal of Zoological Systematics and Evolutionary Research, 43, 321-331.

Nittinger F, Gamauf A, Pinsker W, Wink M, Haring E (2007) Phylogeography and population structure of the saker falcon (Falco cherrug) and the influence of hybridization: mitochondrial and microsatellite data. Molecular Ecology, 16, 1497-1517.

Nyström J, Dalén L, Hellström P, Ekenstedt J, Angleby H, Angerbjörn A (2006) Effect of local prey availability on gyrfalcon diet: DNA analysis on ptarmigan remains at nest sites. Journal of Zoology, 269, 57-64.

Omland KE, Baker JM, Peters JL (2006) Genetic signature of intermediate divergence: population history of Old and New World Holarctic ravens (Corvus corax). Molecular Ecology, 15, 795-808.

Paetkau D, Amstrup SC, Born EW et al. (1999) Genetic structure of the world's polar bear populations. Molecular Ecology, 8, 1571-1584.

Palsbøll PJ, Bérubé M, Allendorf FW (2007) Identification of management units using population genetic data. Trends in Ecology E Evolution, 22, 11-16.

Pamilo P, Savolainen O (1999) Post-glacial colonization, drift, local selection and conservation of populations: a northern perspective. Hereditas, 130, 229-238.

Pearse DE, Crandall KA (2004) Beyond $F_{\mathrm{ST}}$ : analysis of population genetic data for conservation. Conservation Genetics, 5, 585-602.

Pétursson G, Práinsson G, Ólafsson E (1993) Sjaldgæfir fuglar á Íslandi 1991. Bliki, 13, 11-44.

Piertney SB, MacColl ADC, Bacon PJ, Racey PA, Lambin X, Dallas JF (2000) Matrilineal genetic structure and female-mediated gene flow in red grouse (Lagopus lagopus scoticus): an analysis using mitochondrial DNA. Evolution, 54, 279-289.

Potapov E, Sale R (2005) The Gyrfalcon. Yale University Press, New Haven, Connecticut.

Pritchard JK, Stephens M, Donnelly P (2000) Inference of population structure using multilocus genotype data. Genetics, 155, 945-959.

Rice WR (1989) Analyzing tables of statistical tests. Evolution, 43, 223-225.

Roques S, Negro JJ (2005) MtDNA genetic diversity and population history of a dwindling raptorial bird, the red kite (Milvus milvus). Biological Conservation, 126, 41-50.

Rozas J, Sánchez-DelBarrio JC, Messeguer X, Rozas R (2003) DNASP, DNA polymorphism analyses by the coalescent and other methods. Bioinformatics, 19, 2496-2497.

Ruokonen M, Aarvak T, Madsen J (2005) Colonization history of the high-arctic pink-footed goose Anser brachyrhynchus. Molecular Ecology, 14, 171-178.

Slatkin M (1995) A measure of population subdivision based on microsatellite allele frequencies. Genetics, 139, 457-462.

Slatkin M (2005) Seeing ghosts: the effect of unsampled populations on migration rates estimated for sampled populations. Molecular Ecology, 14, 67-73.

Slatkin M, Hudson RR (1991) Pairwise comparisons of mitochondrial DNA sequences in stable and exponentially growing populations. Genetics, 129, 555-562.

Snow C (1974) Gyrfalcon, Falco rusticolus. Habitat management series for unique or endangered species. US Department of Interior, Bureau of Land Management, report No. 9, technical note 241.

Snow DW, Perrins CM (1998) The Birds of the Western Palearctic: Concise Edition, Vol. 1: Non-Passerines. Oxford University Press, Oxford, UK.

Stewart JR, Lister AM (2001) Cryptic northern refugia and the origins of the modern biota. Trends in Ecology \& Evolution, 16, 608-613.

Storz JF (2005) Nonrandom dispersal and local adaptation. Heredity, 95, 3-4.
Sunnucks P (2000) Efficient genetic markers for population biology. Trends in Ecology and Evolution, 15, 199-203.

Taylor BL, Dizon AE (1996) The need to estimate power to link genetics and demography for conservation. Conservation Biology, 10, 661-664.

Todd WEC (1963) Birds of the Labrador Peninsula and Adjacent Areas. Toronto University Press, Toronto, Canada.

Todd WEC, Friedmann H (1947) A study of the gyrfalcons with particular reference to North America. The Wilson Bulletin, 59, 139-150.

Tyrberg T (1998) Pleistocene Birds of the Palearctic: A Catalogue. Publications of the Nuttal Ornithological Club, No. 27, Cambridge, Massachusetts.

Van Coeverden de Groot PJ (2001) Conservation genetic implications of microsatellite variation in the muskox Ovibos moschatus: the effect of refugial isolation and the Arctic Ocean on genetic structure. $\mathrm{PhD}$ Thesis. Queen's University, Ontario, Canada.

Vaurie C (1961) Systematic notes on palearctic birds, no. 45, Falconidae: the genus Falco (part 2). American Museum Novitates, 2038, $1-24$.

Waltari E, Cook JA (2005) Hares on ice: phylogeography and historical demographics of Lepus arcticus, L. othus, and L. timidus (Mammalia: Lagomorpha). Molecular Ecology, 14, 2005-3016.

Waltari E, Demboski JR, Klein DR, Cook JA (2004) A molecular perspective on the historical biogeography of the northern high latitudes. Journal of Mammalogy, 85, 591-600.

Waples RS, Gaggiotti O (2006) What is a population? An empirical evaluation of some genetic methods for identifying the number of gene pools and their degree of connectivity. Molecular Ecology, 15, 1419-1439.

Weider LJ, Hobæk A (2000) Phylogeography and arctic biodiversity: a review. Annales Zoologici Fennici, 37, 217-231.

Weir BS, Cockerham CC (1984) Estimating F-statistics for the analysis of population structure. Evolution, 38, 1358-1370.

Weir JT, Schluter D (2004) Ice sheets promote speciation in boreal birds. Proceedings of the Royal Society of London. Series B, Biological Sciences, 271, 1881-1887.

White CM, Cade TJ (1971) Cliff-nesting raptors and ravens along the Colville River in arctic Alaska. The Living Bird, 10, 107-150.

Whitlock MC, McCauley DE (1999) Indirect measures of gene flow and migration: $F_{\mathrm{ST}} \neq 1 /(4 N m+1)$. Heredity $, \mathbf{8 2}, 117-125$.

Wilson GA, Rannala B (2003) Bayesian inference of recent migration rates using multilocus genotypes. Genetics, 163, 11771191.

Wink M, Sauer-Gürth H, Ellis D, Kenward R (2004) Phylogenetic relationships in the Hierofalco complex (Saker-, Gyr-, Lanner-, Laggar Falcon). In: Raptors Worldwide: Proceedings of the VI World Conference on Birds of Prey and Owls (eds Chancellor RD, Meyburg BU), pp. 499-504. MME/WWGBP, Budapest \& Berlin.

The authors are interested in the evolutionary history and conservation of birds of prey. This study formed part of Kurt Burnham's D.Phil. research conducted at the University of Oxford, and he currently serves as the Arctic Program Director for The Peregrine Fund. Jeff Johnson is a Research Scientist interested in conservation, population genetics and phylogenetics. William Burnham has a long history working in conservation with birds of prey and is President Emeritus of The Peregrine Fund. David Mindell is a Professor and Curator of Birds interested in phylogenetics, conservation, and evolutionary theory. 
Appendix Microsatellite allele frequencies for each locus and sampling location

\begin{tabular}{|c|c|c|c|c|c|c|c|c|c|c|}
\hline \multirow[b]{2}{*}{ Locus } & \multirow[b]{2}{*}{ Allele } & \multicolumn{9}{|c|}{ Sampling locations } \\
\hline & & Thule & Kanger & Scoresby. & Maniitsoq & Canada & Alaska & Iceland & Norway & Saker falcons \\
\hline$(n)$ & & 31 & 16 & 38 & 18 & 9 & 28 & 25 & 13 & \\
\hline Fp13 & 104 & 0.177 & 0.250 & 0.105 & 0.250 & 0.500 & 0.232 & 0.640 & 0.231 & 0.750 \\
\hline Fp13 & 106 & 0.823 & 0.750 & 0.895 & 0.750 & 0.500 & 0.768 & 0.360 & 0.769 & 0.175 \\
\hline Fp13 & 108 & 0 & 0 & 0 & 0 & 0 & 0 & 0 & 0 & 0.075 \\
\hline$(n)$ & & 31 & 16 & 38 & 18 & 9 & 28 & 25 & 13 & 20 \\
\hline Fp54 & 92 & 0.016 & 0.063 & 0 & 0 & 0.111 & 0.107 & 0.060 & 0.231 & 0.075 \\
\hline Fp54 & 106 & 0 & 0 & 0 & 0 & 0.056 & 0.089 & 0 & 0.192 & 0.150 \\
\hline Fp54 & 108 & 0.032 & 0 & 0 & 0.278 & 0.056 & 0.054 & 0 & 0 & 0.150 \\
\hline Fp54 & 110 & 0.016 & 0.031 & 0.132 & 0.194 & 0.167 & 0.232 & 0.140 & 0.039 & 0.375 \\
\hline Fp54 & 112 & 0.339 & 0.250 & 0.276 & 0.278 & 0.111 & 0.036 & 0.180 & 0 & 0.125 \\
\hline Fp54 & 114 & 0 & 0 & 0.013 & 0 & 0 & 0.036 & 0 & 0 & 0.025 \\
\hline Fp54 & 116 & 0.419 & 0.375 & 0.447 & 0.139 & 0 & 0.125 & 0.060 & 0.192 & 0 \\
\hline Fp54 & 118 & 0 & 0.031 & 0.053 & 0 & 0 & 0 & 0.080 & 0.115 & 0.025 \\
\hline Fp54 & 120 & 0 & 0 & 0.013 & 0 & 0.056 & 0 & 0 & 0 & 0 \\
\hline Fp54 & 122 & 0 & 0.063 & 0.013 & 0.056 & 0 & 0 & 0 & 0.077 & 0 \\
\hline Fp54 & 124 & 0 & 0 & 0 & 0 & 0.111 & 0.089 & 0 & 0 & 0.025 \\
\hline Fp54 & 126 & 0.177 & 0.188 & 0.053 & 0.056 & 0 & 0.143 & 0.180 & 0.115 & 0 \\
\hline Fp54 & 128 & 0 & 0 & 0 & 0 & 0.333 & 0.089 & 0 & 0 & 0 \\
\hline Fp54 & 136 & 0 & 0 & 0 & 0 & 0 & 0 & 0.020 & 0 & 0 \\
\hline Fp54 & 138 & 0 & 0 & 0 & 0 & 0 & 0 & 0.060 & 0.039 & 0.050 \\
\hline Fp54 & 140 & 0 & 0 & 0 & 0 & 0 & 0 & 0.220 & 0 & 0 \\
\hline$(n)$ & & 29 & 16 & 37 & 18 & 9 & 28 & 23 & 13 & 20 \\
\hline Fp79-4 & 148 & 0 & 0 & 0 & 0 & 0 & 0 & 0 & 0 & 0.050 \\
\hline Fp79-4 & 150 & 0 & 0 & 0 & 0 & 0 & 0 & 0 & 0 & 0.075 \\
\hline Fp79-4 & 152 & 0 & 0 & 0 & 0 & 0 & 0 & 0 & 0 & 0.150 \\
\hline Fp79-4 & 154 & 0 & 0 & 0 & 0 & 0 & 0.018 & 0.152 & 0 & 0.375 \\
\hline Fp79-4 & 156 & 0.931 & 0.906 & 0.919 & 0.917 & 0.833 & 0.554 & 0.848 & 0.808 & 0.275 \\
\hline Fp79-4 & 158 & 0.069 & 0.094 & 0.081 & 0.083 & 0.167 & 0.393 & 0 & 0.154 & 0 \\
\hline Fp79-4 & 160 & 0 & 0 & 0 & 0 & 0 & 0.036 & 0 & 0 & 0.050 \\
\hline Fp79-4 & 162 & 0 & 0 & 0 & 0 & 0 & 0 & 0 & 0 & 0.025 \\
\hline Fp79-4 & 166 & 0 & 0 & 0 & 0 & 0 & 0 & 0 & 0.039 & 0 \\
\hline$(n)$ & & 31 & 16 & 38 & 18 & 8 & 28 & 25 & 13 & 20 \\
\hline Fp82-2 & 139 & 0 & 0 & 0 & 0 & 0 & 0 & 0 & 0 & 0.025 \\
\hline Fp82-2 & 141 & 0 & 0 & 0 & 0 & 0 & 0 & 0 & 0 & 0.100 \\
\hline Fp82-2 & 143 & 0.452 & 0.188 & 0.368 & 0.361 & 0.063 & 0.214 & 0.040 & 0.115 & 0.175 \\
\hline Fp82-2 & 145 & 0 & 0 & 0 & 0 & 0 & 0 & 0 & 0.039 & 0.050 \\
\hline Fp82-2 & 147 & 0.548 & 0.313 & 0.368 & 0.444 & 0.500 & 0.625 & 0.080 & 0.423 & 0.175 \\
\hline Fp82-2 & 149 & 0 & 0.094 & 0.079 & 0.028 & 0.125 & 0 & 0.100 & 0 & 0.075 \\
\hline Fp82-2 & 151 & 0 & 0.031 & 0 & 0 & 0 & 0 & 0.180 & 0 & 0.125 \\
\hline Fp82-2 & 153 & 0 & 0 & 0 & 0 & 0 & 0 & 0 & 0 & 0.025 \\
\hline Fp82-2 & 155 & 0 & 0.375 & 0.184 & 0.167 & 0.313 & 0.161 & 0.540 & 0.385 & 0.075 \\
\hline Fp82-2 & 157 & 0 & 0 & 0 & 0 & 0 & 0 & 0 & 0.039 & 0.100 \\
\hline Fp82-2 & 161 & 0 & 0 & 0 & 0 & 0 & 0 & 0 & 0 & 0.050 \\
\hline Fp82-2 & 165 & 0 & 0 & 0 & 0 & 0 & 0 & 0 & 0 & 0.025 \\
\hline Fp82-2 & 183 & 0 & 0 & 0 & 0 & 0 & 0 & 0.040 & 0 & 0 \\
\hline Fp82-2 & 187 & 0 & 0 & 0 & 0 & 0 & 0 & 0.020 & 0 & 0 \\
\hline$(n)$ & & 31 & 16 & 38 & 18 & 9 & 28 & 25 & 13 & 20 \\
\hline Fp89 & 126 & 0.855 & 1.000 & 0.632 & 0.806 & 0.944 & 0.893 & 0.780 & 0.808 & 0.950 \\
\hline Fp89 & 128 & 0.145 & 0 & 0.368 & 0.194 & 0.056 & 0.107 & 0.220 & 0.192 & 0.050 \\
\hline
\end{tabular}


$3160 \mathrm{~J}$. A. JOHNSON ET AL.

Appendix Continued

\begin{tabular}{|c|c|c|c|c|c|c|c|c|c|c|}
\hline \multirow[b]{2}{*}{ Locus } & \multirow[b]{2}{*}{ Allele } & \multicolumn{9}{|c|}{ Sampling locations } \\
\hline & & Thule & Kanger & Scoresby. & Maniitsoq & Canada & Alaska & Iceland & Norway & Saker falcons \\
\hline$(n)$ & & 31 & 16 & 38 & 18 & 8 & 28 & 25 & 13 & 20 \\
\hline Fp92-1 & 107 & 0.194 & 0.219 & 0.237 & 0.222 & 0 & 0 & 0 & 0 & 0 \\
\hline Fp92-1 & 113 & 0.742 & 0.750 & 0.724 & 0.722 & 0.875 & 0.804 & 0.520 & 0.423 & 0.750 \\
\hline Fp92-1 & 115 & 0 & 0 & 0 & 0 & 0 & 0 & 0 & 0.1538 & 0.025 \\
\hline Fp92-1 & 117 & 0 & 0 & 0 & 0 & 0 & 0 & 0 & 0 & 0.050 \\
\hline Fp92-1 & 121 & 0.065 & 0.031 & 0.040 & 0.056 & 0.125 & 0.161 & 0.480 & 0.423 & 0.125 \\
\hline Fp92-1 & 123 & 0 & 0 & 0 & 0 & 0 & 0.018 & 0 & 0 & 0.050 \\
\hline Fp92-1 & 125 & 0 & 0 & 0 & 0 & 0 & 0.018 & 0 & 0 & 0 \\
\hline$(n)$ & & 31 & 16 & 38 & 18 & 9 & 28 & 25 & 13 & 20 \\
\hline Fp107 & 211 & 0 & 0 & 0 & 0 & 0 & 0.214 & 0 & 0.154 & 0.150 \\
\hline Fp107 & 212 & 0.355 & 0.438 & 0.605 & 0.639 & 0.889 & 0.607 & 0.080 & 0.731 & 0.425 \\
\hline Fp107 & 213 & 0.645 & 0.563 & 0.395 & 0.361 & 0.111 & 0.179 & 0.920 & 0.115 & 0.425 \\
\hline$(n)$ & & 31 & 16 & 38 & 18 & 8 & 28 & 25 & 9 & 20 \\
\hline Fr34 & 153 & 0.436 & 0.344 & 0.618 & 0.500 & 0.250 & 0.464 & 0.160 & 0.389 & 0.550 \\
\hline Fr34 & 157 & 0.565 & 0.656 & 0.382 & 0.500 & 0.750 & 0.536 & 0.840 & 0.611 & 0.450 \\
\hline
\end{tabular}

